\title{
Management Skills inIT. Implementation of the process in an environment of Vocational Training, case of the Moroccan Office OFPPT
}

\author{
Anajar Abdelhak $^{\mathrm{a}}$, Talbi Mohammed ${ }^{\mathrm{a}}$, Tragha Abderrahim ${ }^{\mathrm{b}}$ \\ ${ }^{a}$ Observatory of Research in Teaching and University Pedagogy (ORDIPU), School of Science Ben M'sik, Hassan II University, \\ Mohammedia-Casablanca,Morocco. \\ ${ }^{b}$ Research Laboratory : Information Processing and Modelisation, School of Science Ben M'sik, Hassan II University, Mohammedia- \\ Casablanca,Morocco.
}

\section{Introduction}

With the opening of the countries' economies to the international competition which has become harder and harder, The Human resources (HR) which were considered for a long time as a "cost to be supported" by companies, is perceived today as "a real investment" that has to be constantly valued in order to take the best advantage of it. Systems of values, attitudes and behaviors which are their results have a considerable influence on the performance level of the staff. The tangible adhesion of the staff in the company'sobjectives and their commitment in the process of change, make today, the reflection on the degree of relevance of unavoidable motivation and evaluation techniques. In spite of the variety of the experiences, the diversity of the diagnoses and the analyses of various companies regarding the problem of Human resources management ( HRM), there is a consensus, not formal, but active, on the necessity of setting up a new conception and a new vision of the HRM.

After the legal and the quantitative, the HRM enters nowadays the age of the human being and willmainly aimto value the human resources by determining and implementing a range of management tools which are the levers to improve the performance and to strengthen the competitiveness. So, the "Managementof skills"became one of the key words of the RH departments' speech. The HRM based on alogic of positions is undermined and often replaced by modes of management calling on the notion of Skill. So, the Management of skills appears as a new approach of the HRM today which surpasses the management by "work position"and this by joining an evolutionary dynamic of research and connection, between work and individuals, which places more emphasison individuals. In fact, the Professional skills take a leading place in the concerns of large companies and individuals. A convergence of interests appears on its subject: the Operational Directions realize more and more that the Skill can be a key resource in obtaining Performance and competitive advantage.

\section{Identify and evaluate the skills}

In spite of its indistinct character, even variable according to the individuals and the structures that uses it, the concept of Skill was imperative in the managerial literature these last years. And not only in that managerial literature: more and more numerous companies develop repository skills , which concern mostly their executives and several times, the members of their highly qualified staff. Nevertheless, the notion of Skill is a newcomer in the vocabulary of the working psychologists, and more generally, the HRM. Abilities, interests and personality traits represent generally parameters according to which the individuals differ from each other. However and more and more often, the requirements of a certain position or an employment, to be provided within a company, are defined by the hierarchy levels in term of Skills.

The Skills are the fruit of experience, but they are acquired on condition that abilities and adequate personality traits are present. It will thus be necessary to take into account in the elaboration of a list of prerequisites not only existing Skills among employees, but also capacities and personality traits that are necessary in order to acquire, from experience, other Skills. So, the analysis of position, is the essential prerequisite of the evaluation, as far as it is during this stage that are identified the Skills, the capacities and the required personality traits

\section{Interest of the place of research}

At present, the Office of the Vocational training and work Promotion (OFPPT) is called to answer major challenges resulting from the perspectives of the Training sector in Morocco and to answer imperatives related to the globalization, the deep transfers that the economic sphere knows, as well as the responsibilities resulting from its new status. However, the OFPPT should, in the fulfillment of its missions, optimize its HRM by managing the costs and the risks and by ensuring at the same time the improvement of the quality and the services which it has to guarantee. It is advisable to indicate, besides, that the system of HRM currently set up in 
the OFPPT is limited to the career management without trying to stimulate and to value the Performance and the Skill of the staff, neither to improve the high potential nor to bring it out. This system, adopted since 2003, began to falter and especially revealed its limits.

\section{Problem}

Today $^{1}$, after the adoption of a reorganization in 2007 and further to a number of established evaluations, the OFPPT wishes to make a commitment in an approach of "Management of skills «to take advantage of its human potential. In response to the new needs of the OFPPT regarding the increasing demand of flexibility, adaptability and reactivity, the organization of work based on the pure tayloriennelogic of the "stabilized" positions within a pyramidal organization chart, seems to be widely outmoded today. The environment of the OFPPT is at present characterized by: widened missions and diversified jobs, an increasing need of expertise; demanding experts and difficult to attract and to retain; local managers to be more involved and a requirement of innovation and exemplary level to the outside. So, The HR DEPARTMENT wishes to set up a new mode of management in order to increase the individual and collective professionalism of the staff, to introduce a capacity to work in mobile structures and to support more and more immaterial activities.

To develop our research, we present, below, the questions which we would try to answer, or at least to give lightings, throughout the realization of this work: The adoption of "Management of skills" would it allow to increase the individual and collective professionalism of the staff, to introduce a capacity to work in mobile structures, to support activities being more and more immaterial and to know better the jobs of OFPPT? Would it be convenient to dash into an approach which, at first sight, seems complex and expensive?

\section{Objectives of research}

We shall try to demonstrate through our research that the "management of skills" is a tool which will allow the OFPPT to know better its jobs so that it will be able to develop the professionalism, theflexibility and the versatility of its employees and, by the same, fit permanently the HR to the needs of the establishment.

In order to prove this, we shall focus on setting up the various components of the "Management of skills" at the level of the chosen perimeter: the Direction of the Organization and the Information systems (DOSI) of the Region of Casablanca.

The choice of this entity justifies itself by the fact that Information systems (IS) constitute today a fundamental pillar on which are based the Systems of Decision-making in training sector ${ }^{2}$

\section{Methodological approach}

We will present a scenario of implementation of an approach based on the GC in the DOSI. And we will illustrate the development of this approach and its implementation. Finally, we will list a number of recommendations to succeed the approach, in terms of options and strategic directions, specific objectives and action plan.

It goes without saying that the implementation of an approach based on the "Management of skills" will require, mainly, the use of two basic tools necessary for the functioning of the concept, namely: the Directory of the Functions and the Skills Repositories. The first one will include, referring to business ${ }^{3}$, jobs and will allow to place every employment located in its general environment. The second will give listed on a hierarchical basis all the Skills related to the jobs. It will constitute the key of the piloting system of the HR. It is from this device that the OFFPT can articulate the study of its jobs and fit the Skill to the requirements of recruitment, mobility and Training.

\section{DOSI as perimeter of research}

The Direction of Organization and Information Systems (DOSI) is responsible for the definition of the OFPPT's organizational and Information System policy, the coordination of the objectives and procedures, assistance for structures interconnected by means of desk or informatics tools, design, implementation and monitoring of contracts programs and dashboards. In addition, the DOSI ensures the coordination of the work of the bodies of governance of the Information System (Committee of informatics strategy and technical InformaticsCommittee). The research approach is to focus on the concept of management of skills at the level of DOSI of Casablanca. The choice of the DOSI, as entity driver being motivated by the following five reasons:

1. The key role played by IS in the training business;

\footnotetext{
${ }^{1}$ See Le Livre Blanc (The white book) to strengthen and consolidate the dynamism of the Moroccan economy, CGEM 2007.

${ }^{2}$ Annual Report of the Court of Auditors, OFPPT, $p^{\circ} 286, .2011$.

${ }^{3}$ For the pilot entity that will be considered in this research, namely DOSI
} 
2. The IS of OFPPT besides being a traditional objective of leverage of efficiency of the process, must make it possible to adapt to rapid and unexpected environment, variationsnow called ecosystem (e.g. needs of pro-activity, modularity, learning). It must also allow the interconnection of IS of the OFPPT with its partners or its clients;

3. The IS of OFPPT becomes strategic when, in addition to its contribution to the efficiency of the process, he takes part in the transformation of the institution and allows it to adapt permanently;

4. In the IS of OFPPT, the complex information management brings a specific contribution, through the enrichment of the workstation or the person, communication and collaboration capabilities, opportunities for reduction of knowledge and know-how. All factors that reflect the wealth of the IS function

5. The large enough size of the executives and agents number at the Regional Direction (about 100 executives and officers);

\section{Diagnosis and Action Plan}

The absence of a real function of MS(Management of Skills) has as direct consequence that the system faces numerous difficulties related notably to :

1. Shortages on the market of the use of the competencies deemed 'rare '. Obviously, this has meant that the OFPPT faces sometimes delicate situations during recruitment campaigns where the resource requirements are not always met.

2. The retention of the OFPPT personnel (with the significant number of resignations ${ }^{4}$ recorded lately);

3. The inability to assess the qualifications held and measure variances for each agent between the required skill level and the actual level;

Despite the difficulties mentioned above and the willingness shown by the management, the practices observed in the field rarely translate (or do not translate) by taking into account the management of jobs and skills at a strategic level, particularly even less at the operational level. The establishment of an approach of MS assumes the necessary prerequisites to the implementation of the concept. Below, we present the various stages which will be addressed in the implementation of the approach:

1. Presentation of the list of functions of the DOSI:This list will include a title and a brief description of each function. We will focus at this level to a description of the currently existing functions at the level of the DOSI or that will exist in the near future pulling advantage of the current trend of functions related to the IS;

2. Presentation of the structure of the Frame of reference of Competences:(Including different types of Competences, their decomposition in groups (Behavior and technical Competences), Competences properly speaking as well as levels of workmanship which will allow to measure up to which degree Competence is assimilated by every agent);

3. Presentation of the different manners of the Frame of reference of Competences:(Including adequacy man/position, identification (following notably the annual discussions of valuation) of Trainings necessary for the acquisition and for the development of Competences, for internal agility, for promotion, etc);

4. Presentation of lists of Repository of Skills:Technical and behavioral skills. This action will be following bibliographic research work first, then confrontation with existing and desirable skills to accomplish under the best conditions inherent to the DOSI missions;

5. Presentation of management rules relative to skill assessment:We will hint at this level especially to the annual assessment interview.

Once all components of the MS have been mastered, the concept could easily be generalized to all structures and entities of the institution 5 .

\section{Practical implementation of the approach}

- The DOSI Functions

The study of the existing functions within the OFPPT DOSI highlights 43 functions that cover all of the functions carried by the Direction. Such functions can be divided into 4 areas:

\footnotetext{
${ }^{4}$ The IF function is the most affected by this phenomenon. We noted a significant number of resignations over the past two years.

${ }^{5}$ However, the success of the implementation of the concept will depend on the consideration of a number of tips and recommendations which will be discussed in the summary of this work.
} 


\begin{tabular}{|c|c|c|c|c|c|}
\hline \multicolumn{5}{|c|}{ Functions related to trades of Studies and Developments (12 functions) } \\
\hline $\begin{array}{c}\text { Head of } \\
\text { Research and } \\
\text { Development }\end{array}$ & $\begin{array}{c}\text { Head of } \\
\text { Service Areas } \\
\text { of ITC and } \\
\text { IT. }\end{array}$ & $\begin{array}{c}\text { Head of } \\
\text { service areas } \\
\text { of trade } \\
\text { support }\end{array}$ & $\begin{array}{c}\text { Head of } \\
\text { service of } \\
\text { supervision of } \\
\text { studies. }\end{array}$ & $\begin{array}{c}\text { Head of } \\
\text { Logistics } \\
\text { Service }\end{array}$ & $\begin{array}{c}\text { IT Project } \\
\text { Manager. }\end{array}$ \\
$\begin{array}{c}\text { Software } \\
\text { Engineer }\end{array}$ & $\begin{array}{c}\text { Development } \\
\text { Technician. }\end{array}$ & $\begin{array}{c}\text { Analyst } \\
\text { Programmer }\end{array}$ & $\begin{array}{c}\text { Head of } \\
\text { Integration } \\
\text { Application } \\
\text { Management } \\
\text { Service. }\end{array}$ & $\begin{array}{c}\text { Information } \\
\text { System } \\
\text { Planner }\end{array}$ & $\begin{array}{c}\text { Integrator of } \\
\text { application. }\end{array}$ \\
\hline
\end{tabular}

\begin{tabular}{|c|c|c|c|c|c|}
\hline \multicolumn{6}{|c|}{ Functions related to trade Infrastructure Management and Production (20 functions) } \\
\hline $\begin{array}{l}\text { Head of the } \\
\text { Department } \\
\text { of } \\
\text { Infrastructur } \\
\text { e and } \\
\text { Production }\end{array}$ & $\begin{array}{l}\text { Head of Technical } \\
\text { Integration Service }\end{array}$ & $\begin{array}{l}\text { Head of Engineering } \\
\text { Department. }\end{array}$ & $\begin{array}{c}\text { Head of IT } \\
\text { Production Service. }\end{array}$ & $\begin{array}{c}\text { Head of management } \\
\text { service of IT park and } \\
\text { Comm }\end{array}$ & $\begin{array}{c}\text { Windows } \\
\text { Systems } \\
\text { and } \\
\text { Network } \\
\text { Administ } \\
\text { rator. }\end{array}$ \\
\hline $\begin{array}{c}\text { Database } \\
\text { administrato } \\
\text { r. }\end{array}$ & $\begin{array}{l}\text { Operations } \\
\text { Technician. }\end{array}$ & Systems Engineer. & Works Preparator & Support technician. & $\begin{array}{l}\text { Security } \\
\text { Administ } \\
\text { rator. }\end{array}$ \\
\hline $\begin{array}{l}\text { Unix } \\
\text { Systems } \\
\text { Administrat } \\
\text { or. }\end{array}$ & Technical Architect. & Security Engineer. & $\begin{array}{l}\text { Network Engineer or } \\
\text { Telecommunications. }\end{array}$ & Technical integrator. & $\begin{array}{l}\text { IT park } \\
\text { manager }\end{array}$ \\
\hline $\begin{array}{l}\text { Tape } \\
\text { librarian. }\end{array}$ & software technician & & & & \\
\hline \multicolumn{6}{|c|}{ Functions related to the business of the Organization ( 7 Functions) } \\
\hline $\begin{array}{l}\text { Head of } \\
\text { Organizatio } \\
\mathrm{n} \\
\text { Department }\end{array}$ & $\begin{array}{l}\text { Head of General } \\
\text { Service } \\
\text { Organization. }\end{array}$ & $\begin{array}{l}\text { Head of Methods } \\
\text { Service. }\end{array}$ & $\begin{array}{l}\text { Head of Quality } \\
\text { Service }\end{array}$ & Organizer. & $\begin{array}{l}\text { Qualitici } \\
\text { an }\end{array}$ \\
\hline $\begin{array}{l}\text { Method } \\
\text { engineer. }\end{array}$ & & & & & \\
\hline \multicolumn{6}{|c|}{ Functions related to the profession of Internal Control (1 Function ) } \\
\hline \multicolumn{6}{|c|}{ Head of Internal Control Service. } \\
\hline \multicolumn{6}{|c|}{ Functions related to Administrative Management and Help Desk trades (3 functions) } \\
\hline $\begin{array}{l}\text { Head of } \\
\text { Administrati } \\
\text { ve Affairs } \\
\text { Service and } \\
\text { Help Desk. }\end{array}$ & $\begin{array}{l}\text { Budget Responsible, } \\
\text { documentation and } \\
\text { Software licenses. }\end{array}$ & Help Desk Operator. & & & \\
\hline
\end{tabular}

- Structure of the repository of skills (RC)

For a better understanding of the concept and better tracking, the RC that we propose in our present research is structured, and this for each competency, in 4 sections described as follows: first a title describing in the clearest way possible and in a way specifies each jurisdiction of the repository; then a definition detailing to each jurisdiction the different characteristics, concepts and possibly the case of use of said jurisdiction. After activities or observable indicators to measure the degree of mastery of each competency and facilitating, in fact, work management and evaluation of the said jurisdiction; Finally some tiered levels describing the degree of relevance as well as professional growth in the field covered by each jurisdiction of repository.

- Uses of the repository of skills 
The RC is a source of information on a daily basis as in the medium and long term. It indeed makes it possible to answer several questions which constitute management for the HRM tools:

- What are the common and different skills between two functions? When it comes to identify cross curricular competencies between several functions or to bring out the typical and specific skills of a function.

- Do the predictable changes in the function imply mastering other skills? This will enable us to decide on the possibility of change of function of a given agent.

- Does the agent have the required skills of his function? To determine the ability of the agent to the position which he is supposed to undertake.

- Doesthe agent have the required skills in his next job? When it is necessary to assign an agent to a new function different from the one undertakes through internal mobility.

- $\quad$ Lists of the skills of the repository

To not set a heavy list hard to make use of later, we will focus in our census on skills which:

- The absence would result in failure: skills that are essential to the holding of a post or a function and thereby to the achievement of the objectives assigned to each function.

- The presence leads to High Performance: the skills of success to improve the quality of work as well as the individual and collective performance

This work has been developed following interviews that were conducted with all officials ${ }^{6}$ of the Directorate. First, we compiled a more or less exhaustive list of potential skills in the Trade Organization and of IS in a general way. This list was thus established following a literature search including level $\mathrm{CIGREF}^{7}$ jobs that have been our main source of information on this subject. Then, the list has been reviewed with each of policymakers in an individual way. Each manager has tried to seeat the level of this list what were the skills necessary for the holding of the functions that he oversaw or he is called to oversee and, taking into account the sites being launched at the Executive level. So more than a dozen meetings were conducted on this subject, which allowed us to refine the list of competencies previously established to keep only 28 skills which we will present further in this work.

For further information to make the approach more pragmatic and more consistent, we tried throughout the interviews we've made to:

-Differentiate the technical skills from the behavioral skills;

-Choose skills that we can observe: through real situations of work or observable behaviours;

-Power measuring skills: through a description in different levels.

It goes without saying that the two types of skills that we have identified (the skills and behavioural) of our driver entity are the result of work carried out in the field with various officials of the DOSI and this, through several meetings and working sessions that were conducted. Note also that this list could, possibly, be reviewed and, following a consultation of all the agents and executives under management.

${ }^{8}$ it is evidently to measure the individual skills of agents since the skills will be frozen (and rarely updated) before the start of the implementation of the approach.

In what follows, we will try to briefly describe the characteristics of skills Techniques (16 identified skills) as well as those related to the behavioral skills (number of 12 competencies) that make up our repository.

i. Technical skills

In the field of organization and IS, the theme of our research, we have highlighted families of technical skills. The first 12 techniques are the Technical Skills to DOSI (Pure Technical Skills), while the last four forms are the Trade Skills that are related to services of OFPPT. We have also chosen to combine the Trade Skills by type of industry, according to the shortening that has been done for the Division of the Organization. This aggregation allows us thus to end up with a reasonable number of skills to manage at the DOSI. We will refer to and for a better understanding, in the description of each Technical Competence, the main IS functions, to which the competence is an essential prerequisite for their occupation:

\footnotetext{
${ }^{6}$ Service managers, departments and the direction headquartered in Casablanca

${ }^{7}$ Network of Big Companies, www.cigref.fr
} 
Management Skills inIT. Implementation of the process in an environment of Vocational Training,

\section{TABLE $N^{\circ} 1$ - Technical Competences}

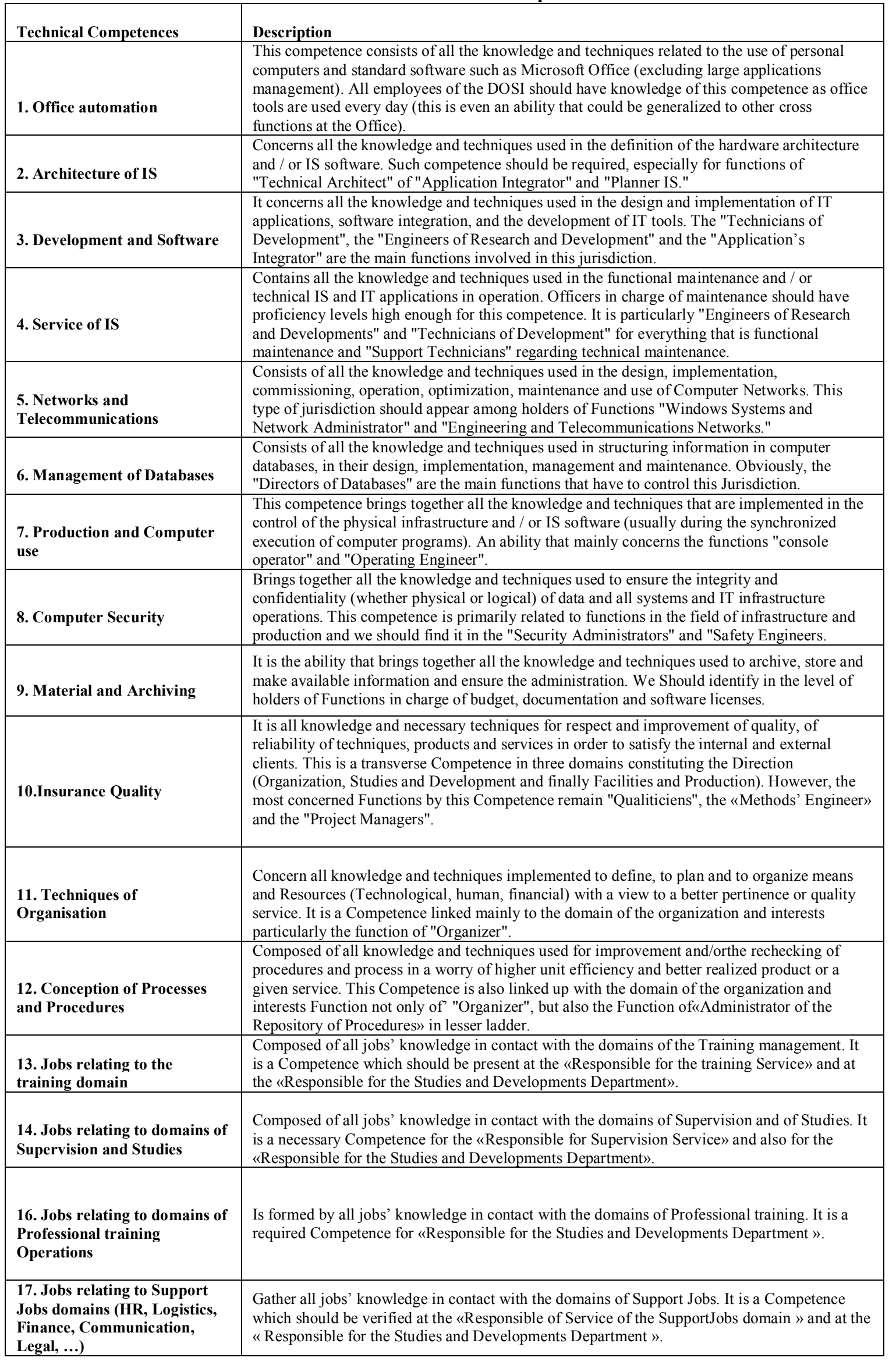


ii. Behavioral Competences

Behavioral Competences are critical to get one Performance superior in a post and this, beyond technical competences. This is the personal attitude and interpersonal skills essential to the implementation of the knowledge and required skills by a function and/or held by a person. These behaviors are based on personal predisposition and can be enhanced by training or professional experience. In what follows, we present the main families of Behavioral Competencies proposed for DOSI and Skills that include are of managerial order (1 to 8) as well as skills related to personal development ( 9 to 12), with, any referrals to functions during the presentation of each competency in which the said Competence should necessarily be present.

\section{TABLE $\mathbf{N}^{\circ} 2$ - behavioral competences}

\begin{tabular}{|c|c|}
\hline Behaviour Competences & Description \\
\hline 1. Delegation / Control & $\begin{array}{l}\text { A Competence which assumes that his possessor can entrust to other people } \\
\text { execution and responsibility of activities, follow realization and control their } \\
\text { results. Such Competence is necessary for the managers as well as all agents } \\
\text { having under their control other collaborators. }\end{array}$ \\
\hline 2. Team leadership & $\begin{array}{l}\text { The Team leadership: Consist in being able to lead group away by } \\
\text { mobilizing energies towards a collective result. Such Competence is } \\
\text { necessary for the managers as well as the agents having under their control } \\
\text { other collaborators. We very especially refer here to the Function of "Project } \\
\text { manager". }\end{array}$ \\
\hline 3. Understanding of others & $\begin{array}{l}\text { Listen and include by showing an immediate interest for what others express, } \\
\text { want to express or cannot express. A primordial Competence for the } \\
\text { managers but also for the "Organizers", "Qualiticiens ", the "Project } \\
\text { Managers" and the «administrators of procedures repository » seen their } \\
\text { permanent contact with management clients. }\end{array}$ \\
\hline 4. Development of others & $\begin{array}{l}\text { Being able to promote, support learning and development of skills for any } \\
\text { initiative beyond the simple framework of Vocational Training. Not only } \\
\text { managers will be affected by this competence but all other employees } \\
\text { (particularly specialists) who, in the exercise of their functions become } \\
\text { involved in developing skills of their colleagues. }\end{array}$ \\
\hline 5. Adaptation & $\begin{array}{l}\text { Include and appreciate other ideas or practices than his, take them into } \\
\text { account to bring some change in his behaviours, methods, decisions and } \\
\text { values. The domain of information and communication technologies is a } \\
\text { domain in perpetual change, so are practices. The specialists of Direction } \\
\text { have to keep this Competence which will allow them to fit to every new } \\
\text { change. }\end{array}$ \\
\hline 6. Conviction/Membership & $\begin{array}{l}\text { It is the Competence which consists in being able to persuade and include his } \\
\text { interlocutors to ideas, projects or points of view. Such Competence is } \\
\text { necessary for the managers as well as all agents having under their control } \\
\text { other collaborators, notably the «Project Managers». }\end{array}$ \\
\hline 7. Decision-Making & $\begin{array}{l}\text { Consists of all the features to make clear choices based on their impact to } \\
\text { concretize, materialize and implement an idea, a project, or an instruction. } \\
\text { Managers are most concerned by this competence, but also "Project } \\
\text { Managers" and employees whose jobs give a contact with internal or external } \\
\text { clients of OFPPT. }\end{array}$ \\
\hline $\begin{array}{l}\text { 8. Declension of stakes and of } \\
\text { strategy }\end{array}$ & $\begin{array}{l}\text { Consists in including stakes and strategically decisions of the institution to } \\
\text { include them into its analyses, decisions and actions. Main characteristic for } \\
\text { the managers, first concerned by the declension of strategic goals in } \\
\text { operational objectives, but also «Project Managers». }\end{array}$ \\
\hline 9. Reliability / Rigour & $\begin{array}{l}\text { Consist in looking after reliability and after quality of results, after precision } \\
\text { of data and all the communicated information. In view of the domain in } \\
\text { which we operate, this Competence should constitute the word of order of } \\
\text { each and every one within Direction and very especially for the agents who } \\
\text { make development such as the "Development technicians" and the « Studies } \\
\text { and Development Engineers». }\end{array}$ \\
\hline $\begin{array}{l}\text { 10. Ethics } \\
\text { and Integrity }\end{array}$ & $\begin{array}{l}\text { This Competence is the fact of being be able to act in keeping with values of } \\
\text { the institution and to be able to subordinate one's own interest to that of the } \\
\text { institution in any circumstances. It is about characteristics which should } \\
\text { inevitably exist in all collaborators. }\end{array}$ \\
\hline 11. Anticipation & $\begin{array}{l}\text { A Competence which consists in envisaging future events, in imagining } \\
\text { scenarios, in initiating actions, implementing them and finally in casting in } \\
\text { future by assessing consequences. The «Methods Engineers» have to keep } \\
\text { this competence since they should stay up to date in technological and } \\
\text { methodological aspects, but will be also concerned by this Competence the } \\
\text { managers and the «Project Managers». }\end{array}$ \\
\hline 12. Reactivity & $\begin{array}{l}\text { Be possible to react with pertinence and speed to an event or information to } \\
\text { get the desired results. A general and valid Competence to all collaborators } \\
\text { of the DOSI. }\end{array}$ \\
\hline
\end{tabular}


- The levels of Competences

In what follows, we propose to introduce a "generic ${ }^{8}$ " grid of levels of control techniques as well as two proficiency levelgrids ${ }^{9}$ for Behavioral Competences. For the latter, we propose to describe these levels for the Skills "Delegation / Control" and "Conducting a team."

i. The levels of Technical Competences

Technical skills will be described in five levels corresponding to degrees ranging from the most basic to the mastery and excellence. As we reported earlier and instead of describing each competence with highly technical terms, which will not only be difficult to identify (or at least require an onerous task) but not favoring an update in the future, we will try to present easily exploitable and generalizable fairly generic levels to all Technical Skills of DOSI and all Office thereafter.

TABLE $\mathrm{N}^{\circ} 3$ - The Levels of Technical Competences

\begin{tabular}{|c|c|}
\hline Levels & Description \\
\hline \multirow[b]{2}{*}{ Level 1} & $\begin{array}{l}\text { This Function requests to be familiarized with the specific vocabulary, simple material elements, procedures and } \\
\text { common practices, the common interveners in this context. }\end{array}$ \\
\hline & $\begin{array}{l}\text { This Function can participate in activities peculiar to the domain, but by envisaged and simple acts that is it does } \\
\text { not request a true professional training, but a simple putting in the picture concerning the elementary use of the } \\
\text { elements of domain and the "logistics" of elements. }\end{array}$ \\
\hline \multirow[b]{2}{*}{ Level 2} & Carry out by applying instructions, procedures and given surgical modes. \\
\hline & $\begin{array}{l}\text { Implement techniques, practices, methods or tools, make common controls by the application of pre-established } \\
\text { and stabilized procedures. Alert from the observation of serious dysfonctions. }\end{array}$ \\
\hline \multirow{3}{*}{ Level 3} & Analyze a common situation, accomplish a diagnosis, choose a solution and resolve a problem. \\
\hline & Know all the technical elements, tools and methods. \\
\hline & Errors are errors concerning the choice of solution \\
\hline \multirow{3}{*}{ Level 4: } & $\begin{array}{l}\text { Control the theoretical foundations of domain allowing to accomplish studies, diagnoses or predictions from } \\
\text { existent models, to establish conditions of contract and adequate procedures. }\end{array}$ \\
\hline & $\begin{array}{l}\text { Define norms, methodologies or appropriate tools, control technological and methodological evolutions peculiar } \\
\text { to the domain. }\end{array}$ \\
\hline & Errors are errors of conception of the implementation devices. \\
\hline Level 5 & $\begin{array}{l}\text { Detain a group of knowledge whose deepening and exploration degree, variety of perception and high level of } \\
\text { pertinence workmanship allow to create new concepts. }\end{array}$ \\
\hline
\end{tabular}

ii. Levels of behavioral Competences

We present here the levels of mastery for Competence "Delegation / control" and "Conducting team." The same pattern can be used for the 10 remaining Behavioral Skills. In this case also, the Behavioural Competencies are described in 5 levels corresponding todegrees ranging from the elementary (low use or possession of Competence) than perfect mastery (the employee makes a perfect use and an exemplary application of Competence).

\section{- Competence «Delegation/Control»}

TABLE $\mathbf{N}^{\circ} 4$

\begin{tabular}{|l|l|}
\hline Levels & Description \\
\hline \multirow{3}{*}{ Level 1 } & An objective look to the capacities of others to take care of additional activities \\
\cline { 2 - 2 } Level 2 & Entrust tasks to his immediate collaborators \\
\cline { 2 - 2 } & Solicit punctually his close environment to allocate him a part of its activity whennecessary \\
\cline { 2 - 2 } Level 3 3 Sheal pedagogic worry and explain "why " in detail and «how to» and makes sure that the agent understood \\
\cline { 2 - 2 } & $\begin{array}{l}\text { Sets out to identify in a rational way, in his perimeter, the activities which he can entrust to collaborators in a worry of } \\
\text { optimization }\end{array}$ \\
\cline { 2 - 2 } Level 4 & Implements everything to favour the autonomy of the agent \\
\hline \multirow{4}{*}{ Level 5 } & $\begin{array}{l}\text { Defines, in keeping with the agent, the conditions of taking care of his mission } \\
\text { responsibilities entrusted to their way by giving if necessary to the persons concerned the possibility of fulfilling }\end{array}$ \\
\cline { 2 - 2 } & $\begin{array}{l}\text { Defines principles and conditions of implementation of delegation / controle policy and oversees that it is implemented at all } \\
\text { levels of the institution }\end{array}$ \\
\hline
\end{tabular}

- Competence «Conducting team»

\footnotetext{
${ }^{8}$ Available to all technical skills, from simple knowledge to effective leadership..

${ }^{9}$ Since these specific skills, each behavioral competence must have its own reference grid.
} 
Management Skills inIT. Implementation of the process in an environment of Vocational Training,

\begin{tabular}{|l|l|}
\hline \multirow{2}{*}{ Levels } & Description \\
\hline \multirow{3}{*}{ Level 1 } & Develop a climate of confidence within his team (s). \\
\cline { 2 - 2 } Level 2 & Kn followed by the members of his team (s) in his proposals, decisions and actions. \\
\cline { 2 - 3 } Level 3 & Is admitted by the quality of its proposals. \\
\hline \multirow{3}{*}{ Level 4 } & Use occasions with discretion to show example in terms of waited behaviours. \\
\hline & $\begin{array}{l}\text { Has the worry to create a real dynamic around the strategic vision of the institution or around the plans which implicate } \\
\text { change }\end{array}$ \\
\cline { 2 - 3 } & Implements everything to morally and psychically support all his team(s) members. \\
\hline & Defines and shares a stimulating vision for the institution and its different elements. \\
\cline { 2 - 3 } & $\begin{array}{l}\text { Sets out to motivate and to federate energies permanently of all collaborators towards the attack of common objectives } \\
\text { defined beforehand. }\end{array}$ \\
\cline { 2 - 3 } & Shows exemplary charisma and exercises a decisive influence for the attack of fixed objectives. \\
\hline
\end{tabular}

- Valuation of Competences and qualification of voids to fill

Following the results, the step of the evaluation is to assess the level of mastery of critical skills for each agent. It includes the following actions :

- Implementation of a system of valuation of Competences (such as support of maintenance of valuation);

- Initial diagnosis of actual skills held by each employee;

- Possible revision, of tools assistant to the valuation of levels of Competences and in the detection of potential;

- Training of the managers to get rational and objective valuation of levels of Competences (valuation of Competences kept being a strong instant in the annual maintenance, it is a question of transmitting to the managers a «methodological kit» who reminds of fundamental recommendations and who allows them to be comfortable and pertinent during this exercise);

- Revision of individual profiles of Competences by updating individual profiles of Competences detained from valuation transmitted by evaluators;

- Strengthening of levels of Competences: wallets of Competences subject to mobilization by job, by Direction, and, across the establishment of a consolidated vision, a transverse and synthetic material of profiles individual of Competences;

- Analysis of acquisition rhythms and of underlying trends of the phenomena of acquisition, of development and of loss of Competences within OFPPT (rhythms, structural reasons, incurred risks, opportunities, experimentation to be driven ...).

Qualification gap fill is to highlight individually the most disabling differences in skills through a confrontation between the profiles of skills required and those actually held by each agent. The elementary actions that constitute this step are:

- Confrontation between critical Competences for the implementation of strategy and wallet of Competences indeed detained by the agents from OFPPT. So, and from the reference of profiles of Competences requested by the Function, it is necessary to highlight individually the gapsbetween profiles (we will put, at the same time, in obviousness, one of important levers of adequacy "Man /post");

- Skills the most important distances the most risky and most critics (it is necessary to spot at this occasion most well-known expertise and deficiencies);

- Emphasis of the most important distances. It is necessary to try of their search short-term reasons or those who are the most structural for the accomplishment of objectives allocated to jobs and, by the same, in every Function.

\section{Recommendations}

The purpose of a MS (Management of Skills) is not only to contribute to the competitiveness requirements of the institution, it is also and above all to promote the employability of its employees (with all that this could bring as advantage to the organization and for the individual himself), that is to say the ability to cope with changes in jobs and the possibility of a change of employment. 
To encourage this or the employability internal mobility, and beyond the successful implementation of the MS approach, we cite, below some recommendations that we believe will be key success factors that must be provided in the MS process as established in the previous sections:

- Clarify in advance, motivations and objectives of OFPPT in the implementation of such an approach.

- Communication on this approach is a condition sine qua non for success. It is a shame to compromise by a lack of clarity on the reasons for it and the objectives that underlie it. Officials must approach and explain to all agents the merits of the approach in responding simply to the question "Why".

- Taking the time to a preliminary diagnosis. The skills approach cannot be improvised. Like any strategic investment, it involves upstream analysis to determine its economic relevance, identification of levers or specific to the culture of the organization and an inventory of social dialogue brakes. Such a diagnosis will, without doubt, be a valuable insight into the state of its strengths and weaknesses. By prior diagnosis, we do not mean economic audit, strategic or financial.

- Objective is not to develop a comprehensive picture of the situation, but only to examine systematically the key factors to consider when launching the Skills ${ }^{10}$ approach. It is of course also essential to review the practices and possibly existing tools for skills. This diagnostic work may possibly be led by the company itself. However, most experts feel richer and more objective analysis made by an outsider.

- Facility of the consultation of Skills Repositories to Employees. In fact, all employees should have access to that repository to find the skills they hold and are validated by the system (Individual Skills), then the competencies required for all existing jobs and that he might be interested first. A note about the vital role to be played by the New Technologies of Information and Communication to develop and facilitate access to these repositories.

- Organize around these repositories, a device of reflection and dialogue to facilitate the understanding of trend assumptions Qualifications and evolutionary factors that impact them. This will allow everyone within the organization to better prepare his career path through individualized development skills.

${ }^{10}$ "Engineering and skills assessment (Third Edition)" ( Guy Le Boterf) Organization editions, 2012. 